|| ISSN(online): 2589-8698 || ISSN(print): 2589-868X || International Journal of Medical and Biomedical Studies

Available Online at www.ijmbs.info

Volume 3, Issue 2; February: 2019; Page No. 168-173

PubMed (National Library of Medicine ID: 101738825)

Index Copernicus Value 2017: 40.03

\title{
ROLE OF VITAMIN D IN ENDOTHELIAL CELL OF RETINA
}

Dr. Sonpal Jindal ${ }^{1}$, Dr. Mukesh Kumar Taneja ${ }^{2}$

${ }^{1}$ Assistant Professor Dept. of Ophthalmology K.M. Medical College and Hospital, Mathura (UP).

${ }^{2}$ Assistant Professor Dept. of Ophthalmology K.M. Medical College and Hospital, Mathura (UP).

Article Info: Received 10 November 2018; Accepted 26 December. 2018

Cite this article as: Jindal, Dr. S., \& Taneja, Dr. M. K. (2019). ROLE OF VITAMIN D IN ENDOTHELIAL CELL OF RETINA. International Journal of Medical and Biomedical Studies, 3(2).

DOI: https://doi.org/10.32553/ijmbs.v3i2.605

Address for Correspondence: Dr. Mukesh Kumar Taneja, Assistant Professor Dept. of Ophthalmology, K.M. Medical College and Hospital, Mathura (UP).

Conflict of interest: No conflict of interest.

\section{Abstract}

Vitamin D deficiency is a common health problem worldwide. Many parts of the human eye, including the epithelium of the cornea, lens, ciliary body, and retinal pigment epithelium, as well as the corneal endothelium, ganglion cell layer, and retinal photoreceptors, contain vitamin $D$ receptor. Physiological effects of vitamin D From an ocular point of view, the role in macular and retinal health had been advanced, as well as the involvement in corneal inflammatory response, wound healing, and dry eye disease. The most important effect of vitamin $D$ is on, phosphorus, calcium metabolism and on bone mineralization. Recently, it was observed that vitamin D deficiency and insufficiency are related with common cancers, cardiovascular diseases, metabolic syndromes, infectious, and many chronic diseases including autoimmune disease. Benefits of vitamin D may be amplified through synergistic interaction with topical corticosteroids which accelerates improvement in corneal shape and optics, substantially benefiting the control of ocular surface disease and dry eye symptoms. Aqueous humour is the primary source responsible for the feeding of corneal endothelial layer hence endothelial abnormalities can be expected due to accumulated inflammatory cytokines and multiple toxic products in the aqueous humour of the patients with vitamin D deficiency.

MATERIAL AND METHODS: Subjects were selected with vitamin D deficiency in the age group of 20-55 years. 50 patients having serum vitamin D levels $<15 \mathrm{ng} / \mathrm{ml}$ were included in the study. Serum vitamin $D$ levels of $<15 \mathrm{ng} / \mathrm{ml}$ were included in the control group. Vitamin D levels in tear fluid were measured by direct competitive chemiluminescent enzyme linked immunoassay. A complete ophthalmic evaluation was performed in all participants which includes assessment of visual acuity, anterior segment evaluation and posterior segment evaluation. Specular microscopy was performed on the eyes of the patients with vitamin D deficiency and healthy control group individuals. Corneal endothelial cell density (CD) and central corneal thickness (CCT) values were calculated automatically using the software of the specular microscope.

RESULTS: The study group included 23 male and 27 female subjects while study group included 24 male and 26 female. Mean age of male in study group was $46.4 \pm 12.56$ and female was $45.6 \pm 11.77$. In control group mean male age was $48.5 \pm 9.25$ and female age was $49.56 \pm 12.55$. In study group Mean Corneal endothelial cell density (CD) was observed as $2632.89 \pm 189.25 \mathrm{cells} / \mathrm{mm}^{2}$ and Mean central corneal thickness (CCT) was $587.2 \pm 25.89 \mu$. In control group Mean Corneal endothelial cell density (CD) was observed as $2954.97 \pm 116.89$ cells $/ \mathrm{mm}^{2}$ and Mean central corneal thickness (CCT) 
was $546.0 \pm 36.22 \mu$. Vitamin D levels of Tears in study group was $8.4 \pm 1.7 \mathrm{ng} / \mathrm{ml}$ and in control group it was $16.2 \pm 2.3 \mathrm{ng} / \mathrm{ml}$.

CONCLUSION: It has been observed that there is statistically significant difference in the corneal endothelial cell density (CD) and central corneal thickness (CCT) in patients with vitamin D deficiency. It was observed that Vitamin $D$ is present in tear fluid and there is significant difference in the levels of vitamin D in study and control group.

\section{Introduction:}

Vitamin $D$ deficiency is a common health problem worldwide. Many parts of the human eye, including the epithelium of the cornea, lens, ciliary body, and retinal pigment epithelium, as well as the corneal endothelium, ganglion cell layer, and retinal photoreceptors, contain vitamin D receptor (VDR) [1]. Physiological effects of vitamin D From an ocular point of view, the role in macular and retinal health had been advanced, as well as the involvement in corneal inflammatory response, wound healing, and dry eye disease [2].Vitamin $D$ is a group of fatsoluble vitamin which can be synthesized by the body under appropriate biological conditions. It includes vitamin D3 (cholecalciferol) and vitamin D2 (ergocalciferol). In the liver hepatocytes, vitamin D3 is converted to calcidiol (calcifediol) 25-hydroxyvitamin D3 $(25[\mathrm{OH}] \mathrm{D} 3)$ and vitamin D2 is converted to 25-hydroxyergocalciferol $(25[\mathrm{OH}] \mathrm{D} 2)$ by the 25 -hydroxylase. $25(\mathrm{OH}) \mathrm{D} 3$ is converted to 1,25-dihydroxycholecalciferol $(1,25[\mathrm{OH}] 2 \mathrm{D} 3$-calcitriol), the active form of vitamin $\mathrm{D} 3$ by $1 \alpha$ hydroxylase in the kidneys and many tissues. To determine the vitamin $D$ status in serum, these two vitamin D metabolites are measured [3].

The most important effect of vitamin $D$ is on, phosphorus, calcium metabolism and on bone mineralization. Recently, it was observed that vitamin $D$ deficiency and insufficiency are related with common cancers, cardiovascular diseases, metabolic syndromes, infectious, and many chronic diseases including autoimmune diseases [4]. Vitamin D3 increases the production of antiinflammatory cytokines and reduces the production of pro-inflammatory cytokines thus playing important role in inflammatory process
$[5,6]$. Aqueous humor is the primary source responsible for the feeding of corneal endothelial layer hence endothelial abnormalities can be expected due to accumulated inflammatory cytokines and multiple toxic products in the aqueous humor of the patients with vitamin $D$ deficiency.

The receptors for Vitamin $D$ receptor (VDR) are expressed in the cornea, lens, ciliary body, retina, and retinal pigment epithelium and polymorphisms in the receptor and its start codon have been linked to myopia of the eye [7, 8 , 9]. The keratoconus and other forms of keratoectasia, following refractive surgery, can be significantly improved by adequate vitamin D supplementation. Also benefits of vitamin D may be amplified through synergistic interaction with topical corticosteroids which accelerates improvement in corneal shape and optics, substantially benefiting the control of ocular surface disease and dry eye symptoms [10].

Our aim of the study was to see whether corneal endothelium is affected by the vitamin $D$ deficiency as it causes inflammation, oxidation, and apoptosis.

\section{MATERIAL AND METHODS}

The present study was carried out in Dept. of Ophthalmology at K. M. Medical College and Hospital, Mathura (UP). The present study was approved by the institutional review board. 50 subjects were selected with vitamin $D$ deficiency in the age group of $20-55$ years. 50 patients having serum vitamin $D$ levels $<15 \mathrm{ng} / \mathrm{ml}$ were included in the study. Serum vitamin $D$ levels of $<15 \mathrm{ng} / \mathrm{ml}$ were included in the control group. Written informed consent was obtained from all the participants in study group and control group. Subjects were excluded if they had any 
significant history of ocular disease, refractive surgery, corneal reshaping, bifocals or the use of atropine. Also systemic disease such as diabetes mellitus and hypertension, previous ocular surgery or laser therapy, history of any corneal disorder, trauma history, and glaucoma were excluded from the study. Vitamin D levels in tear fluid were measured by direct competitive chemiluminescent enzyme linked immunoassay.

A complete ophthalmic evaluation was performed in all participants which includes assessment of visual acuity, anterior segment evaluation and posterior segment evaluation after dilating pupils by $+90 \mathrm{D}$ bio-microscopy to rule out certain posterior segment conditions such as glaucoma.
Specular microscopy was performed on the eyes of the patients with vitamin D deficiency and healthy control group individuals. Corneal endothelial cell density (CD) and central corneal thickness (CCT) values were calculated automatically using the software of the specular microscope

Statistical analysis was done with SPSS software. The mean or median value of the individual groups was reported as Mean \pm SEM or median (along with the range). Two-tailed $p<0.05$ was considered to be statistically significant.

\section{OBSERVATIONS AND RESULTS}

The study group included 23 male and 27 female subjects while study group included 24 male and 26 female.

Table 1: Study and control group

\begin{tabular}{lllll}
\hline Group & Male & Female & Mean age Male & Mean age Female \\
\hline Study group & 23 & 27 & $46.4 \pm 12.56$ & $45.6 \pm 11.77$ \\
\hline Control group & 24 & 26 & $48.5 \pm 9.25$ & $49.56 \pm 12.55$ \\
\hline
\end{tabular}

Mean age of male in study group was $46.4 \pm 12.56$ and female was $45.6 \pm 11.77$. In control group mean male age was $48.5 \pm 9.25$ and female age was $49.56 \pm 12.55$.

Table2: Vitamin D level study and control group

\begin{tabular}{llll}
\hline Group & Male & Female & Total \\
\hline Study group & $7.56 \pm 3.25$ & $5.23 \pm 2.21$ & $6.26 \pm 3.10$ \\
\hline Control group & $48.55 \pm 9.56$ & $46.22 \pm 10.22$ & $47.22 \pm 9.98$ \\
\hline P value & $\mathrm{P}<0.0001$ & $\mathrm{P}<0.0001$ & $\mathrm{P}<0.0001$ \\
\hline
\end{tabular}

Intraocular pressure, anterior segment bio microscopic examinations, and posterior segment findings were normal in study as well as in control groups. Corneal endothelial cell density (CD), and central corneal thickness (CCT) values were calculated.

Table 3: Corneal endothelial cell density (CD), and central corneal thickness (CCT)

\begin{tabular}{llll}
\hline Group & $\begin{array}{l}\text { Mean Corneal endothelial } \\
\text { cell density (CD) }\end{array}$ & $\begin{array}{l}\text { Mean central corneal } \\
\text { thickness }(C C T)\end{array}$ & $\begin{array}{l}\text { Vitamin D level in } \\
\text { Tears }\end{array}$ \\
\hline Study group & $2632.89 \pm 189.25$ cells $/ \mathrm{mm}^{2}$ & $587.2 \pm 25.89 \mu$ & $8.4 \pm 1.7 \mathrm{ng} / \mathrm{ml}$ \\
\hline Control group & $2954.97 \pm 116.89$ cells $/ \mathrm{mm}^{2}$ & $546.0 \pm 36.22 \mu$ & $16.2 \pm 2.3 \mathrm{ng} / \mathrm{ml}$ \\
\hline Difference & 322.080 & -41.200 & 7.800 \\
\hline Standard error & 31.458 & 6.296 & 0.404 \\
\hline $\begin{array}{l}\mathbf{9 5 \%} \text { Cl } \\
\text { (Confidence Interval) }\end{array}$ & 259.6535 to 384.5065 & -53.6948 to -28.7052 & 6.9973 to 8.6027 \\
\hline t-statistic & 10.239 & & 19.284 \\
\hline DF & 98 & -6.544 & 98 \\
\hline Significance level & $\mathrm{P}<0.0001$ & 98 & $\mathrm{P}<0.0001$ \\
\hline
\end{tabular}


In study group Mean Corneal endothelial cell density (CD) was observed as $2632.89 \pm 189.25$ cells $/ \mathrm{mm}^{2}$ and Mean central corneal thickness (CCT) was $587.2 \pm 25.89 \mu$. In control group Mean Corneal endothelial cell density (CD) was observed as $2954.97 \pm 116.89$ cells $/ \mathrm{mm}^{2}$ and Mean central corneal thickness (CCT) was 546.0 $\pm 36.22 \mu$. Vitamin D level of Tears in study group was $8.4 \pm 1.7 \mathrm{ng} / \mathrm{ml}$ and in control group it was $16.2 \pm 2.3 \mathrm{ng} / \mathrm{ml}$. Statistically significant difference was observed in study group as well as in control group in regard to Mean Corneal endothelial cell density (CD), Mean central corneal thickness (CCT) and Vitamin D levels of Tears.

\section{DISCUSSION AND CONCLUSION}

Blood levels of vitamin $D$ has been related to the dietary variables. There is positive association between increased calcium in the diet and increased vitamin $D$ levels in the blood [11]. Lower levels of vitamin $D$ have been found in the obese [12]. Vitamin D deficiency has been linked to dry eye [8]. There is a protective role for vitamin $D$ for macular degeneration [13]. In an observation it is found that beneficial responses are usually only seen when the serum $25(\mathrm{OH}) \mathrm{D} 3$ level rises above $50 \mathrm{ng} / \mathrm{cc}$ and optimal response begins around $70-80 \mathrm{ng} / \mathrm{cc}$ [14]. Vitamin $D$ is known for modulating the expression of various inflammatory cytokines in various cells which includes corneal epithelial cells [15] and correction of vitamin $D$ deficiency reversed symptoms in a case of corneal neuralgia [16]. Vitamin $\mathrm{D}$ (both 25-hydroxyvitamin $\mathrm{D}_{3}$ and 1, 25dihydroxyvitamin $D_{3}$ ) was shown to influence corneal epithelial barrier function by regulating expression of occluding [17].

In our study Vitamin D was measured in human tears by competitive chemiluminescent immunoassay and it was found that a vitamin $D$ level in serum of study group was $6.26 \pm 3.10$ and in control group was $47.22 \pm 9.98$. This was statistically significant. In tears vitamin $D$ levels were $8.4 \pm 1.7 \mathrm{ng} / \mathrm{ml}$ in study group and $16.2 \pm 2.3 \mathrm{ng} / \mathrm{ml}$ in control group. In a study it was found that the 25-hydroxyvitamin D level was significantly higher in the tears than in the serum [18]. Also in, another study reported significantly higher 25 -hydroxyvitamin $D$ levels in tears $(71.8 \pm 6.2 \mathrm{ng} / \mathrm{ml})$ compared to serum $(21.8 \pm 11.3 \mathrm{ng} / \mathrm{ml})$ in children $(12.5 \pm 2.5$ years $)$ using electro chemiluminescent immunoassay [19].

Oxidation, inflammation, and angiogenesis in the ocular tissues may lead to dysfunction and cell loss and vitamin $D$ inhibits the production of proinflammatory cytokines, including interleukin (IL)-2, IL-12, interferon- $\gamma$, and tumor necrosis factor- $\alpha$ [20]. In a study by Codoner-Franch et. al. [21], demonstrated that lower vitamin $D$ levels have association with higher levels of oxidative stress biomarkers including plasma malondialdehyde and nitrotyrosine concentrations in obese children. In our study significant difference was observed in Mean Corneal endothelial cell density (CD), Mean central corneal thickness (CCT) and Vitamin D level of Tears of vitamin $D$ deficiency patients and control group. It has been demonstrated that vitamin $D$ is able to regulate proliferation and cell differentiation, apoptosis, angiogenesis, and gene regulation. Also in animal studies it has been demonstrated that the exposure of vitamin D to lymphocytes results in decreased cell proliferation and apoptosis [22]. In our study endothelial indices such as CD and CCT were abnormal in study group showing corneal endothelial layer being affected. As the sample size is small we cannot conclude the study but in our study it has been observed that there is statistically significant difference in the corneal endothelial cell density (CD) and central corneal thickness (CCT) in patients with vitamin D deficiency. It was observed that Vitamin $D$ is present in tear fluid and there is significant difference in the levels of vitamin $D$ in study and control group.

\section{REFERENCES}

1. Kizilgul M, Kan S, Ozcelik O, Beysel S, Apaydin M, Ucan B, Cakal E. Vitamin D 
Replacement Improves Tear Osmolarity in Patients with Vitamin D Deficiency. Semin Ophthalmol. 2018;33(5):589-594

2. Jee D, Kang S, Yuan C, Cho E, Arroyo JG. Serum 25-hydroxyvitamin D levels and dry eye syndrome: differential effects of vitamin D on ocular diseases. [Aug;2016];. PLoS One. 2016 11:0.

3. Raposo L, Martins S, Ferreira D, Guimaraes JT, Santos AC. Vitamin D, parathyroid hormone and metabolic syndrome - The PORMETS study. BMC EndocrDisord 2017;17:71.

4. Cherniack EP, Levis S, Troen BR. Hypovitaminosis D: A widespread epidemic. Geriatrics 2008;63:24-30.

5. Cole $\mathrm{N}$, Krockenberger $\mathrm{M}$, Bao $\mathrm{S}$, Beagley $\mathrm{KW}$, Husband AJ, Willcox $M$, et al. Effects of exogenous interleukin-6 during Pseudomonas aeruginosa corneal infection. Infect Immun 2001;69:4116-9.

6. Stromnes IM, Goverman JM. Osteopontininduced survival of $T$ cells. Nat Immunol 2007;8:19-20.

7. Alsalem JA, Patel D, Susarla R. Characterization of vitamin $D$ production by human ocular barrier cells. Invest Ophthalmol Vis Sci. 2014;55: 2140-2147.

8. Annamaneni $\mathrm{S}$, Bindu $\mathrm{CH}$, Reddy $\mathrm{KP}$, Vishnupriya S.Association of vitamin $D$ receptor gene start codon (Fok1) polymorphism with high myopia. Annamaneni S, Bindu CH, Reddy KP, Vishnupriya S. Oman J Ophthalmol. 2011; 4:57-62.

9. Mutti DO, Cooper ME, Dragan E, et al. Vitamin $D$ receptor (VDR) and groupspecific component (GC, vitamin D-binding protein) polymorphisms in myopia. Invest Ophthalmol Vis Sci. 2011;52:3818-3824.

10. McMillan J. Spectrum of Darkness, Agent of Light: Myopia, Keratoconus, Ocular Surface Disease, and Evidence for a Profoundly Vitamin D-dependent Eye. Muacevic A, Adler JR, eds. Cureus. 2018;10(6):e2744.

11. Sinotte $M$, Diorio $C$, Berube $S$, Pollak $M$, Brisson J. Genetic polymorphisms of the vitamin $D$ binding protein and plasma concentrations of 25-hydroxyvitamin D in premenopausal women. Am J ClinNutr. 2009;89: 634-640.

12. Zamboni G, Antoniazzi F, Spolettini E, Tato L. Mineral metabolism in obese children after weight loss. ActaPaediatr Scand. 1991;80: 470-471.

13. Jee D, Kang S, Yuan C, Cho E, Arroyo JG, Epidemiologic Survey Committee of the Korean Ophthalmologic Society.Serum 25Hydroxyvitamin D Levels and Dry Eye Syndrome: Differential Effects of Vitamin D on Ocular Diseases.PLoS One. 2016; 11(2):e0149294.

14. Holick MF, Binkley NC, Bischoff-Ferrari HA, Gordon CM, Hanley DA, Heaney RP, Murad $\mathrm{MH}$, Weaver CM, Endocrine Society. Evaluation, treatment, and prevention of vitamin D deficiency: an Endocrine Society clinical practice guideline.J ClinEndocrinol Metab. 2011 Jul; 96(7):1911-30.

15. Suzuki T, Sano Y, Sotozono C, Kinoshita S. Regulatory effects of 1alpha,25dihydroxyvitamin $D(3)$ on cytokine production by human corneal epithelial cells.. Curr Eye Res. 2000 Feb; 20(2):127-30.

16. Singman EL, Poon D, Jun AS. Putative corneal neuralgia responding to vitamin $d$ supplementation. Case Rep Ophthalmol. 2013; 4(3):105-8.

17. Yin Z, Pintea V, Lin Y, Hammock BD, Watsky MA. Vitamin D enhances corneal epithelial barrier function. Invest Ophthalmol Vis Sci. 2011;52(10):7359-64. doi: 10.1167/iovs.117605.

18. Sethu S, Shetty R, Deshpande K, et al. Correlation between tear fluid and serum vitamin $D$ levels. Eye and Vision. 2016;3(1):22. doi:10.1186/s40662-016-00537.

19. Goksugur SB, Erdurmus $M$, Bekdas $M$, Erkocoglu M, Agca S, Tosun M, et al. Tear and serum vitamin $D$ levels in children with allergicrhinoconjunctivitis. Allergollmmunop athol (Madr) 2015;43(6):533-7. 
Dr. Sonpal Jindal et al, International Journal of Medical and Biomedical Studies (IJMBS)

20. Penna G, Adorini L 1 alpha, 25-dihydroxy vitamin D3 inhibits differentiation, maturation, activation, and survival of dendritic cells leading to impaired alloreactive $\mathrm{T}$ cell activation. J Immunol 2000; 164:2405-11.

21. Codoñer-Franch $P$, Tavárez-Alonso $S$, SimóJordá R, Laporta-Martín P, Carratalá-Calvo A,
Alonso-Iglesias $\mathrm{E}$, et al. Vitamin D status is linked to biomarkers of oxidative stress, inflammation, and endothelial activation in obese children. J Pediatr 2012; 161: 848-54.

22. Holick MF. Vitamin D deficiency. N Engl J Med 2007; 357: 266-81. 